\title{
Efektifitas Pengembangan Buku Ajar Berbasis Nilai-Nilai Karakter Multikultural Terhadap Keterampilan Berpikir Kritis Siswa
}

\author{
Sony Ari Wibowo, Murtono, Santoso, Sri Utaminingsih \\ sony.ariwibowo@umk.ac.id, murtono@umk.ac.id, santoso.bk@umk.ac.id, sri.utaminingsih@umk.ac.id \\ Magister Pendidikan Dasar, Fakultas Keguruan dan Ilmu Pendidikan, Universitas Muria Kudus
}

\begin{abstract}
This study aims to describe the effectiveness of multicultural-based learning to improve students' critical thinking skills in elementary schools. This is a Research and Development $(R$ $\& D)$, with the steps of potential problems analysis, data collection, product design, design validation, design revisions, product trials, and product revisions. This research was conducted in grade IV in SD 1 Tritis and SD 1 Karangnongko, combined as the experimental group, while $S D 1$ Daren and SD 3 Nalumsari as a control group, all in Nalumsari District, Jepara Regency. The results showed the t-test results found that t arithmetic $>T$ table is 8.994> 1699, the value data were analyzed with a significance level of 0.05. So, as the basis for decision making, it can be concluded that Ho was rejected and Ha was accepted. Thus, it can be concluded that multicultural-based learning is effective in improving the critical thinking skills of fourth grade students of elementary schools.
\end{abstract}

Keyword: Effectiveness, Teaching Books, Multicultural, Students Critical Thinking Skills

Article Info

Received date: 7 Desember 2019
Accepted date: 19 Januari 2021

\section{PENDAHULUAN}

Pendidikan merupakan proses perubahan tingkah laku manusia menuju pada kedewasaan. Pendidikan juga diartikan sebagai upaya yang terorganisasi berencana dan berlangsung secara terusmenerus sepanjang hayat untuk membina siswa menjadi lebih baik. Sehingga diharapkan dapat berorientasi pada pengembangan seluruh aspek potensi siswa, baik aspek kognitif, afektif, dan berimplikasi pada aspek psikomotorik. Perkembangan pendidikan pada era globalisasi menuntut para ahli dalam bidang pendidikan untuk mengembangkan berbagai inovasi untuk memajukan siswa yang berkualitas dan berkarakter. Sistem pembelajaran haruslah menempatkan siswa sebagai subjek dalam pembelajaran hal ini bertujuan untuk menuntut keterlibatan intelektual, emosional, pengetahuan, tindakan, serta pengalaman langsung dalam rangka pembentukan keterampilan dari segi motorik, kognitif, dan sosial serta internalisasi nilai-nilai dalam pembentukan sikap. Sehingga pengajaran yang dilakukan menjadi bermakna.

Pembelajaran yang bermakna yaitu pembelajaran yang berpusat pada siswa, sistem pembelajaran yang mengarahkan keterpusatan kepada siswa akan dapat menumbuhkan dan mengembangkan kreativitas dan melatih kemampuan berpikir kritis siswa dalam pembelajaran maupun dalam memecahkan permasalahan yang dihadapi dalam kehidupan sehari-hari. Kemampuan berfikir kristis dinilai penting dimiliki oleh setiap orang yang hidup era revolusi indusri 4.0. Hal ini dikarenakan keterampilan yang harus dikuasai pada era ini harus seimbang antara softskill dan hardskill dalam menanggapi berbagai persoalan. Sejalan dengan hal tersebut (Barry, 2012) mengungkapkan bahwa keterampilan yang harus dikuasai orang di era revolusi industri meliputi keterampilan berpikir kritis, komunikasi, kepemimpinan, kolaborasi, kemampuan beradaptasi, produktifitas dan akuntabilitas, inovasi, kewarganegaraan global, kemampuan dan jiwa entrepreneurship, serta kemampuan untuk mengakses, menganalisis, dan mensintesis informasi. Berikut pendapat para ahli mengenai pengertian berfikir kritis. Fisher (2008:13), menyatakan "Berpikir kritis adalah aktivitas terampil, yang bisa dilakukan dengan lebih baik atau sebaliknya, dan pemikiran kritis yang baik akan memenuhi beragam standar intelektual, seperti kejelasan, relevansi, kecukupan, koherensi, dan lain-lain". Lebih lanjut Susanto (2016: 121), menjelaskan "Berpikir kritis merupakan suatu kegiatan melalui cara berpikir tentang ide atau gagasan yang berhubungan dengan konsep yang diberikan atau masalah yang 
dipaparkan". Berdasarkan pendapat diatas, berpikir kritis berkaitan dengan asumsi bahwa berpikir merupakan potensi yang ada pada manusia yang perlu dikembangkan untuk kemampuan yang optimal.

Kemampuan berfikir kritis dinilai sangat dibutuhkan oleh individu dalam kehidupannya. Sehingga guru dituntut untuk dapat mengembangkan kemampuan berfikir kritis siswa. Hal ini sejalan dengan tuntutan pembelajaran abad 21. (Bahr, 2010) dalam penelitiannya menyampaikan, "It is time for us teachers to play a decisive role in changing the spoon-feeding education paradigm and help our learners develop critical thinking skills and foster human values. Critical thinking skills and subject matter are not mutually exclusive but complementary. Our world needs people who really care about how to restore integrity, promote welfare, equity and social justice; our world needs critical thinkers". Penelitian tersebut juga diperkuat oleh, (Skills, 2011) menemukan, "Those who can think critically and communicate effectively must build on a base of core academic subject knowledge. Within the context of core knowledge instruction, students must also learn the essential skills for success in today's world, such as critical thinking, problem solving, communication and collaboration".

Berdasarkan pendapat diatas salah satu wadah yang tepat untuk melatih dan meningkatkan kualitas berfikir kiritis seseorang adalah dalam pendidikan sebagai bekal bagi siswa menyiapkan diri untuk terjun dalam masyarakat. Oleh sebab itu, guru sebagai ujung tombak dalam pendidikan dituntut untuk mampu mengetahui, menggali, hingga mengembangkan kemampuan berfikir kritis siswa dalam proses pembelajaran. Mengembangkan berpikir kritis di dalam pendidikan berarti seorang guru memberikan penghargaan kepada peserta didik sebagai pribadi (respect a person) dimana siswa diberikan kesempatan yang sama untuk berperan aktif dalam pembelajaran.

Selanjutnya dalam penerapan berfikir kritis. Guru harus mengetahui indikator aspek berfikir kritis. Adapun indikator aspek berfikir kritis yang berkaitan dalam materi pembelajaran dijelaskan secara detail oleh Susanto (2016:125), yaitu (1) memberikan penjelasan sederhana, (2) membangun keterampilan dasar, (3) menyimpulkan, (4) memberikan penjelasan lanjut, dan (5) mengatur strategi dan taktik. keterampilan berpikir kritis siswa perlu dikembangkan mulai dari sekolah dasar melalui pembiasaan-pembiasaan dalam pembelajaran sebagai upaya meningkatkan keterampilan berpikir kritis siswa.

Penerapan berfikir kritis dapat disisipkan dalam mata pelajaran salah satunya muatan Bahasa Indonesia di kelas IV Tema 4. Hal ini dikarenakan materi dalam tema 4 ini sangat dekat dengan segala aktivitas masyarakat sehari-hari begitu pula dengan lingkungan siswa. Namun berdasarkan observasi dan wawancara yang telah dilakukan, ditemukan bahwa pembelajaran yang berlangsung belum sepenuhnya meningkatkan keterampilan berfikir kritis siswa. Data wawancara dan observasi terlihat siswa belum dapat memahami materi yang diajarkan oleh guru, yang membuat siswa merasa terbebani dalam pembelajaran dan menghambat pengembangan keterampilan berpikir kritis siswa. siswa pasif dalam kegiatan pembelajaran, sehingga proses pembelajaran belum terpusat pada siswa sebagai objek. Guru sudah berinovasi dalam mengembangkan kegiatan pembelajaran diantaranya menggunakan model inkuiri, problem based learning, dan lain sebagainya tetapi belum maksimal, dan guru belum menggunakan media pembelajaran secara optimal. Dilihat dari segi bahan bacaan dan teks pendukung yang tersedia dalam buku siswa dan buku guru masih belum sesuai dengan lingkungan yang dihadapi oleh siswa. Bahan bacaan dan teks pendukung kurang menyisipkan pendidikan mutikultural dan kurang mencerminkan permasalahan yang ada secara nyata di lingkungan sekitar siswa, hal ini mengakibatkan pembelajaran kurang kontekstual dengan pengalaman hidup siswa yang sebenarnya. Dilihat dari keberagaman yang ada, ditemukan keberagaman gender laki-laki dan perempuan, ras kulit putih dan hitam, ras rambut lurus dan kriting, dan strata sosial, hal ini tentu perlu pemahaman akan keberagaman yang muncul pada tiap-tiap siswa.

Sebagai salah satu alternatif untuk mengatasi kelemahan-kelemahan dalam peningkatan keterampilan berpikir kritis berkaitan dengan proses pembelajaran diperlukan sebuah pengembangan pembelajaran, salah satu pengembangan pembelajaran yang dapat dilakukan adalah dengan mengembangkan bahan ajar sebagai penunjang dalam meningkatkan keterampilan berpikir kritis siswa. Bahan ajar yang menarik mampu mendorong siswa untuk meningkatkan keterampilan berpikir kritisnya. Sehingga peneliti tertarik mengkaji dan menguji efektifitas pengembangan buku ajar berbasis nilai-nilai karakter multikultural terhadap keterampilan berpikir kritis siswa. 


\section{KAJIAN PUSTAKA}

Pokok pembahasan dalam kajian pustaka ini akan mengkaji lebih dalam reverensi yang mendukung kajian dalam penelitian yang dilakukan.

\section{a. Landasar Bahan Ajar}

Bahan ajar sebagai sumber belajar dalam kegiatan pembelajaran sangat diperlukan. Bahan ajar memiliki peran yang pokok dalam pembelajaran termasuk dalam pembelajaran tematik. Pembelajaran tematik pada dasarnya adalah perpaduan dari berbagai disiplin ilmu, maka pembelajaran ini memerlukan bahan ajar yang lebih lengkap dan komprehensif. Ditinjau dari pengertiannya bahan ajar menurut Prastowo (2014:138) "Bahan ajar merupakan segala bahan (baik itu informasi, alat, maupun teks) yang disusun secara sistematis yang menampilkan sosok utuh dari kompetensi yang akan dikuasai siswa dan digunakan dalam proses pembelajaran dengan tujuan untuk perencanaan dan penelaahan implementasi pembelajaran”. pengembangan pembelajaran Bahasa Indonesia dengan menggunakan bahan ajar harus disesuaikan dengan tuntutan kurikulum dan kebutuhan siswa dengan karakteristik dan lingkungan sosial siswa.

Lebih lanjut, Prastowo (2014:141), menjelaskan manfaat dan pembuatan bahan ajar dibedakan menjadi dua macam, yaitu kegunaan bagi guru dan siswa. Bagi guru, kegunaan penyusunan bahan ajar paling tidak ada delapan macam, yaitu (1) Diperoleh bahan ajar yang sesuai tuntutan kurikulum dan sesuai kebutuhan siswa, (2) Tidak lagi tergantung pada buku teks yang terkadang sulit untuk diperoleh, (3) Bahan ajar menjadi lebih kaya karena dikembangkan dengan menggunakan berbagai referensi, (4) Menambah khazanah pengetahuan dan pengalaman guru dalam menulis bahan ajar, (4) Bahan ajar akan mampu membangun komunikasi pembelajaran yang efektif antara guru dan siswa karena siswa akan merasa lebih percaya diri pada gurunya, (5) Diperoleh bahan ajar yang dapat membantu dalam pelaksanaan kegiatan pembelajaran, (6) Dapat diajukan sebagai kary yang dinilai untuk menambah angka kredit untuk keperluan kenaikan pangkat, dan (7) Menambah penghasilan guru jika hasil karyanya diterbitkan. Bagi siswa sendiri, jika bahan ajar yang dibuat itu bervariasi, inovati dan menarik, maka paling tidak ada tiga kegunaan bahan ajar bagi siswa, yaitu (1) Kegiatan pembelajaran menjadi lebih menarik, (2) Akan lebih banyak mendapatkan kesempatan untuk belajar secara mandiri dengan bimbingan guru, (3) Akan mendapatkan kemudahan dalam mempelajari setiap kompetensi yang harus dikuasainya.

\section{b. Landasan Multikultural}

Saptono (2011:122), menyatakan "Secara preskriptif, multikultural adalah model kebijakan publik untuk mengelola keragaman budaya dalam masyarakat majemuk sedangkan secara deskriptif, multikultural mengacu pada kondisi masyarakat beragam budaya pada suatu wilayah dan masa tertentu". Pendidikan multikultural merupakan fenomena relative baru dalam dunia pendidikan, namun pendidikan multikultural perlu diterapkan sejak dini baik dalam pendidikan formal maupun non formal, implementasi pendidikan multikultural dianggap salah satu cara yang tepat untuk dapat menanamkan kemampuan masyarakat hidup dalam keberagaman dan rasa saling toleransi antar sesama.

Mahfud (2006:169), menjelaskan pendidian multikultural mencakup seluruh siswa tanpa membedabedakan kelompok-kelompoknya seperti gender, etnic, ras, budaya, strata sosial, dan agama. Pada prinsipnya, pendidikan multikultural adalah pendidikan yang menghargai perbedaan. Suryana (2015:199), menjelaskan tujuan pendidikan multikultural adalah (1) untuk membantu siswa, (2) Memahami latar belakang diri dan kelompok dalam masyarakat, (3) Menghormati dan mengapresiasi ke-bhinneka-an budaya dan sosio-historis etnik, (4) Menyelesaikan sikap-sikap yang terlalu etnosentris dan penuh purbasangka, (5) Memahami faktor-faktor sosial, ekonomis, psikologis, dan historis yang menyebabkan terjadinya polarisasi etnik ketimpangan dan keterasingan etnik, (6) Meningkatkan kemampuan menganalisis secara kritis masalah-masalah rutin dan isu melalui proses demokratis melalui sebuah visi tentanng masyarakat yang lebih baik, adil, dan bebas, dan (7) Mengembangkan jati diri yang bermakna bagi semua orang Berdasarkan hal tersebut maka peneliti melakukan penelitian dengan judul "Peningkatan Keterampilan Berpikir Kritis Siswa Melalui Pembelajaran Berbasis Multikultural". Pengembangan pembelajaran berbasis multikultural merupakan suatu solusi pengembangan pembelajaran yang cocok dalam meningkatkan keterampilan berpikir kritis siswa. Penelitian ini bertujuan untuk mendeskripsikan keefektifan pembelajaran berbasis multikultural untuk meningkatkan keterampilan berpikir kritis siswa di Sekolah Dasar. 


\section{c. Penelitian yang Relevan}

Penelitian yang relevan dengan penelitian dan pengembangan ini, diantaranya penelitian dan pengembangan yang dilakukan oleh (Lestariningsih \& Suardiman, 2017), tentang pengembangan bahan ajar tematik-integratif berbasis kearifan lokal untuk meningkatkan karakter peduli dan tanggung jawab. Penelitian dan pengembangan ini dilaksanakan di kelas IV MIN Jejeran. Hasil penelitian menunjukkan bahwa bahan ajar yang dikembangkan layak untuk digunakan. Bahan ajar ini efektif untuk meningkatkan karakter peduli dan tanggung jawab siswa. Terdapat perbedaan yang signifikan karakter peduli dan tanggung jawab siswa sebelum dan sesudah mengikuti pembelajaran dengan menggunakan bahan ajar tematik integratif berbasis kearifan lokal. Persamaan dengan penelitian yang penulis lakukan adalah pada pengembangan bahan ajar, sedangkan perbedaannya terletak pada fokus peningkatan yaitu peneliti fokus meningkatkan karakter peduli dan tanggung jawab sedangkan penulis fokus pada peningkatan keterampilan berpikir kritis.

Hasil penelitian (Melindawati, 2016), dalam penelitiannya yang berjudul pengembangan bahan ajar tematik terpadu dengan model problem based learning di kelas IV sekolah dasar. Penelitian dan pengembangan ini bertujuan mengembangkan bahan ajar tematik terpadu yang praktis dan efektif. Hasil penelitian menunjukkan bahwa bahan ajar yang dikembangkan telah valid dan dapat digunakan dalam pembelajaran tematik terpadu, bahan ajar tematik terpadu dengan model PBL di kelas IV sekolah dasar dinyatakan praktis, dan aktivitas siswa selama pembelajaran sangat baik dan hasil belajar menunjukkan hasil yang efektif. Persamaan dengan penelitian yang penulis lakukan adalah pada pengembangan bahan ajar, sedangkan perbedaannya terletak pada berbasiskan buku ajar yaitu peneliti mengembangkan bahan ajar berbasiskan model problem based learning sedangkan penulis mengembangkan bahan ajar bahasa Indonesia berbasiskan multikultural.

\section{METODE PENELITIAN}

Jenis penelitian yang digunakan dalam penelitian ini adalah Research and Development ( $\mathrm{R} \&$ D). Tujuan penelitian pengembangan ini yaitu mengembangkan pembelajaran berbasis multicultural untuk meningkatkan keterampilan berpikir kritis. Penelitian ini dilaksanakan di kelas IV SD 1 Tritis dan SD 1 Karangnongko, sebagai kelompok eksperimen dan SD 1 Daren dan SD 3 Nalumsari sebagai kelompok kontrol di Kecamatan Nalumsari Kabupaten Jepara. Teknik pengumpulan data dalam penelitian dan pengembangan ini dilakukan melalui Observasi, Wawancara, Kuesioner/Angket, dan Dokumentasi. Observasi digunakan dengan melakukan pengamatan terhadap pembelajaran oleh guru dan siswa kelas IV SD di Kecamatan Nalumsari Kabupaten Jepara. Wawancara dalam penelitian ini ditujukan pada guru dan siswa kelas IV Sekolah dasar. Kuesioner/angket dalam penelitian ini digunakan untuk mengumpulkan data penilaian mengenai bahan ajar. Pengumpulan data tentang efektifitas bahan ajar yang ditujukan kepada guru dan siswa kaitannya dengan pengembangan pembelajaran berbasis multikultural. Kemudian metode dokumentasi dilakukan untuk memperkuat data yang diperoleh dalam observasi. Untuk memberikan gambaran secara konkret mengenai kegiatan kelompok siswa dan menggambarkan suasana kelas ketika aktivitas belajar berlangsung digunakan dokumen foto.

Model pengembangan yang digunakan dalam penelitian ini menggunakan model Borg dan Gall. Menurut Borg dan Gall (1989), penelitian R \& D dalam pendidikan meliputi sepuluh langkah, yakni: (1) Research and Information colletion, (2) Planning, (3) Develop Preliminary form of Product, (4) Preliminary Field Testing, (5) Main Product Revision, (6) Main Field Testing, (7) Operational Product Revision, (8) Operational Field Testing, (9) Final Product Revision, dan (10) Disemination and Implementasi.

Namun dalam penelitian ini hanya sampai pada tahap 7 yaitu Operational Product Revision atau revisi produk. Hal ini dikarenakan keterbatasan waktu dan lain halnya. Berikut merupakan alur prosedur penelitian yang dilaksanakan 
Efektifitas Pengembangan Buku Ajar Berbasis Nilai-Nilai Karakter Multikultural Terhadap

Keterampilan Berpikir Kritis Siswa (Sony Ari Wibowo, Murtono, Santoso, Sri Utaminingsih)

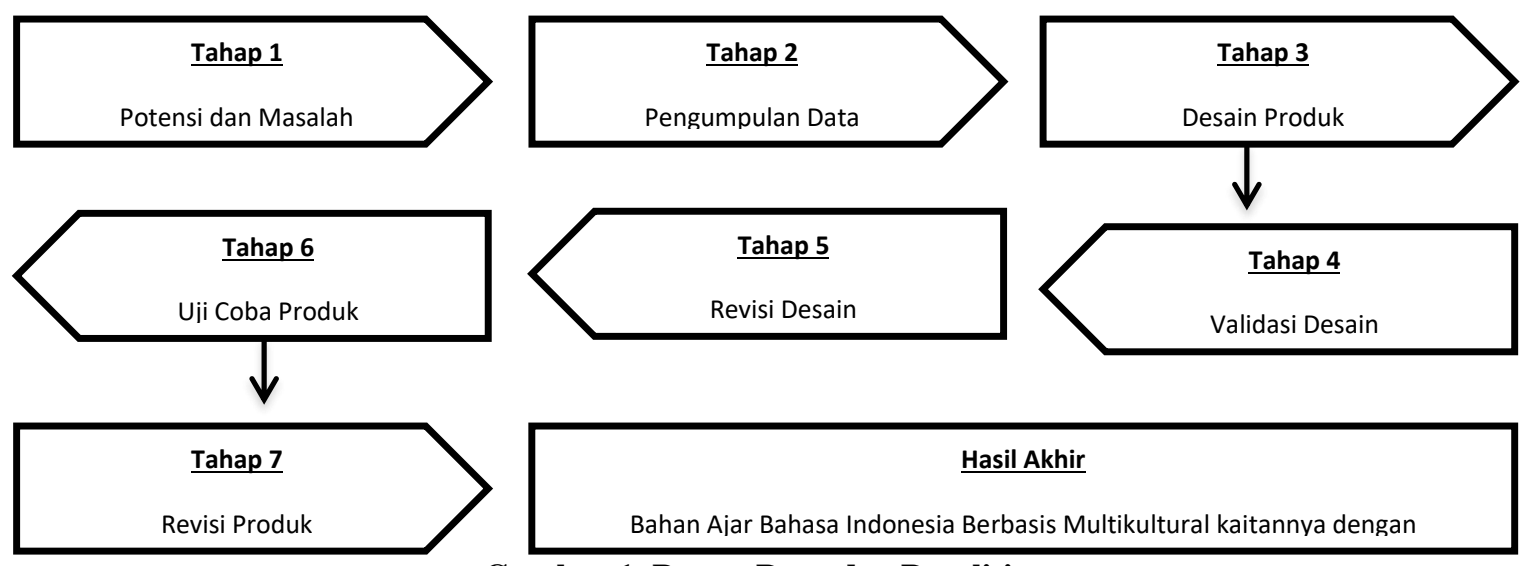

Gambar 1. Bagan Prosedur Penelitian

\section{HASIL PENELITIAN DAN PEMBAHASAN}

\section{Hasil Analisis Kebutuhan Bahan Ajar}

Peneliti melakukan observasi untuk mengetahui situasi sebenarnya yang ada dilapangan. Observasi dalam penelitian ini dilaksanakan pada kelas IV di SD 1 Daren, SD 1 Karangnongko, SD 1 Tritis dan SD 3 Nalumsari. Berdasarkan hasil observasi pada beberapa sekolah dasar di kabupaten Jepara yang dijadikan sebagai obyek penelitian, peneliti menemukan bahwa masih banyak siswa yang belum dapat memahami materi yang diajarkan oleh guru, yang membuat siswa merasa terbebani dalam pembelajaran dan menghambat pengembangan keterampilan berpikir kritis siswa, Hal ini dibuktikan dengan masih rendahnya nilai hasil belajar Bahasa Indonesia Tema 4 berbagai Pekerjaan siswa kelas IV.

\section{Hasil Uji Coba Produk (Keefektifan Bahan Ajar Bahasa Indonesia Berbasis Multikultural)}

Produk berupa bahan ajar Bahasa Indonesia berbasis multikultural ini telah divalidasi oleh tiga validator. Validasi tersebut menghasilkan bahan ajar yang layak untuk dipakai sebagai bahan ajar Bahasa Indonesia berbasis multikultural pada tema 4 berbagai pekerjaan di kelas IV sekolah dasar.

\section{Uji Prasyarat}

Uji prasyarat dilakukan untuk melihat data berdistribusi normal atau tidak dan kelompok data homogen atau tidak. Untuk itu dilakukan uji normalitas dan homogenitas data sebagai berikut.

\section{a. Uji Normalitas}

Uji normalitas dilakukan untuk mendeskripsikan apakah antara kelompok eksperimen dan kelompok kontrol berdistribusi normal atau tidak. Salah satu cara untuk mendeteksi kenormalan sebuah data dapat dilakukandengan teknik shapiro wilk. Adapun hasil uji normalitas shapiro wilk menggunakan SPSS. Adapun hasil uji normalitas shapiro wilk menggunakan SPSS sebagai berikut.

Tabel 1.1 Uji normalitas kelompok eksperimen dan kelompok control Tests of Normality

\begin{tabular}{|c|c|c|c|c|c|c|c|}
\hline \multirow[b]{2}{*}{ Kelompok } & \multicolumn{3}{|c|}{ Kolmogorov-Smirnov ${ }^{\mathrm{a}}$} & \multicolumn{4}{|c|}{ Shapiro-Wilk } \\
\hline & Statistic & Df & Sig. & Statistic & Df & Sig. & \\
\hline $\begin{array}{l}\text { Kelompok } \\
\text { Eksperimen }\end{array}$ & ,118 & 38 & ,200* & ,937 & 38 & &, 035 \\
\hline $\begin{array}{l}\text { Kelompok } \\
\text { Kontrol }\end{array}$ & ,185 & 30 & ,010 & ,940 & 30 & & ,091 \\
\hline
\end{tabular}

Sumber: Data primer, uji normalitas kelompok eksperimen dan kelompok control

Dari tabel tersebut diketahui nilai signifikansi untuk kelompok eksperimen sebesar 0,035 dan nilai signifikansi untuk kelompok kontrol sebesar 0,091. Karena nilai signifikansi untuk kedua kelompok tersebut $>$ 0,05, 75 maka sebagaimana dasar pengambilan keputusan dalam uji normalitas shapiro wilk dapat disimpulkan bahwa data nilai berpikir kritis siswa untuk kelompok eksperimen dan kelompok kontrol berdistribusi normal. 


\section{b. Uji Homogenitas}

Berdasarkan uji homogenitas, diketahui nilai signifikansi (sig.) variabel nilai keterampilan berpikir kritis siswa pada siswa kelompok eksperimen dan kelompok kontrol adalah sebesar 0,013. Karena nilai signifikansi 0,013 > 0,05 maka sebagaimana dasar pengambilan keputusan dalam uji homogenitas, dapat disimpulkan bahwa varians data nilai keterampilan berpikir kritis siswa kelompok eksperimen dan kelompok kontrol adalah sama atau homogen. Adapun hasil uji homogenitas menggunakan SPSS sebagai berikut.

Tabel 1.2 Uji homogenitas kelompok eksperimen dan kelompok kontrol

\begin{tabular}{rrrrr}
\multicolumn{4}{c}{ Test of Homogeneity of Variances } \\
\hline \multicolumn{1}{c}{ devene Statistic } & df1 & df2 & Sig. \\
\hline 3,535 & 4 & 47 &, 013
\end{tabular}

Sumber: Data primer, uji homogenitas kelompok eksperimen dan kelompok control

Selanjutnya berdasarkan uji t, diketahui $t$ hitung bernilai positif yaitu sebesar 8,994. Kemudian $t$ tabel dicari berdasarkan df (derajat kebebasan) dan nilai signifikansi $(\alpha / 0)$. Dari output di atas diketahui nilai df adalah sebesar 29 dan nilai 0,05/0 sama dengan 0,05. Nilai ini digunakan sebagai dasar acuan dalam mencari nilai $\mathrm{t}$ tabel pada distribusi nilai $\mathrm{t}$ tabel statistik. Maka di peroleh nilai $t$ tabel adalah sebesar 1,699. Didapatkan bahwa $t$ hitung $>t$ tabel yaitu 8,994 $>1699$, maka sebagai mana dasar pengambilan keputusan dapat disimpulkan bahwa Ho ditolak dan Ha diterima. Adapun hasil uji t menggunakan SPSS sebagai berikut.

Tabel 1.3 Uji t kelompok eksperimen dan kelompok kontrol Paired Samples Test

\begin{tabular}{|c|c|c|c|c|c|c|c|c|c|}
\hline & & \multicolumn{5}{|c|}{ Paired Differences } & \multirow[b]{3}{*}{$\mathrm{T}$} & \multirow[b]{3}{*}{ df } & \multirow{3}{*}{$\begin{array}{l}\text { Sig. }(2- \\
\text { tailed })\end{array}$} \\
\hline & & \multirow[b]{2}{*}{ Mean } & \multirow{2}{*}{$\begin{array}{c}\text { Std. } \\
\text { Deviation }\end{array}$} & \multirow{2}{*}{$\begin{array}{l}\text { Std. Error } \\
\text { Mean }\end{array}$} & \multicolumn{2}{|c|}{$\begin{array}{c}95 \% \text { Confidence } \\
\text { Interval of the } \\
\text { Difference }\end{array}$} & & & \\
\hline & & & & & Lower & Upper & & & \\
\hline Pair 1 & $\begin{array}{l}\text { Eksperimen } \\
\text { - Kontrol }\end{array}$ & 7,267 & 4,425 &, 808 & 5,614 & 8,919 & 8,994 & 29 & ,000 \\
\hline
\end{tabular}

Sumber: Data primer, uji t kelompok eksperimen dan kelompok kontrol

Dari paparan tersebut dapat disimpulkan bahwa pengembangan pembelajaran berbasis multikultural sangat dibutuhkan dalam menunjang proses pembelajaran dan meningkatkan keterampilan berpikir kritis siswa. Pengembangan pembelajaran dengan mengembangkan bahan ajar Bahasa Indonesia berbasis multikultural ini juga dapat mempermudah guru dalam menyampaikan materi.

\section{Pembahasan}

Pembelajaran berbasis multicultural diangap memiliki dampak yang positif dalam dunia pendidikan. Penelitian mengenai hal tersebut sudah banyak sekali dilakukan oleh peneliti, dimana peneliti menguji efektivitas pembelajaran multicultural, dampak, serta membandingkan dengan pembelajaran lainnya. Hasil dari penelitian- penelitian tersebut dinilai ada respon postif baik bagi guru maupun siswa. Penelitian yang dilakukan oleh (Leung et al., 2008), "The result assume that multicultural experience fosters creativity. In line with this assumption, the research reported in this article is the first to empirically demonstrate that exposure to multiple cultures in and of itself can enhance creativity. Overall, the authors found that extensiveness of multicultural experiences was positively related to both creative performance (insight learning, remote association, and idea generation) and creativity-supporting cognitive processes (retrieval of unconventional knowledge, recruitment of ideas from unfamiliar cultures for creative idea expansion)'. Dampak kemampuan berfikir kritis juga dapat membekali siswa dalam menghadapi kehidupan dan segala problematikan. 
Sejalan dengan pandangan tersebut, (Karakoc, 2016) menyebutkan ciri-ciri orang yang mempunyai kemampuan berfikir kritis sebagai berikut. "Critical thinking individuals are people who research, question, refuse the information's as it is, active, think analytically and synthesis, evaluate the information and explain with true basis, treat open-minded and aware of thinking processes".

Berdasarkan hasil penelitian yang telah diuraikan terhadap peningkatan keterampilan berpikir kritis siswa melalui pembelajaran berbasis multikultural, dapat diambil simpulan bahwa pengembangan pembelajaran berbasis multikultural melalui bahan ajar Bahasa Indonesia efektif dalam meningkatkan keterampilan berpikir kritis siswa. Hasil uji efektifitas menunjukkan bahwa pembelajaran Bahasa Indonesia berbasis multikultural efektif digunakan dalam kegiatan pembelajaran. Hasil dari uji t pada kelompok eksperimen dan kontrol yaitu 8,994. Adapun hasil uji $t$ didapatkan bahwa $t_{\text {hitung }}>t_{\text {tabel }}$ yaitu $8,994>1699$. Pengembangan pembelajaran berbasis multikultural sangat dibutuhkan guru dalam memberikan pengalaman belajar yang bervariasi dan menyenangkan sehingga siswa tertarik, aktif, dan termotivasi untuk mengikuti pembelajaran di kelas, dan menanamkan pendidikan multikultural sebagai wujud toleransi dan menghormati perbedaan yang muncul dalam proses pembelajaran.

Uji efektifitas bahan ajar Bahasa Indonesia berbasis multikultural dilaksanakan dengan menghitung nilai keterampilan berpikir kritis siswa kelompok eksperimen dan kelompok kontrol. Nilai rata-rata keterampilan berpikir kritis siswa pada kelompok eksperimen adalah 86 dengan nilai tertinggi yang dicapai siswa adalah 92 dan nilai terendah yang dicapai siswa adalah 76. Kemudian nilai rata-rata keterampilan berpikir kritis siswa pada kelompok kontrol adalah 79 dengan nilai tertinggi yang dicapai siswa adalah 82 dan nilai terendah yang dicapai siswa adalah 76. Berdasarkan nilai ratarata keterampilan berpikir kritis siswa tersebut menunjukkan bahwa penggunaan bahan ajar Bahasa Indonesia berbasis multikultural efektif digunakan untuk meningkatkan keterampilan berpikir kritis siswa dalam pembelajaran Bahasa Indonesia tema 4 berbagai pekerjaan pada kelas IV sekolah dasar di Kabupaten Jepara.

Keefektifan bahan ajar Bahasa Indonesia berbasis multikultural diperkuat pula dengan hasil penelitian dari (Indrawini et al., 2017), dalam penelitiannya yang berjudul pengembangan bahan ajar tematik subtema ayo cintai lingkungan untuk siswa kelas IV SD. Penelitian dan pengembangan ini dilaksanakan di SDN Nogotirto. Tujuan penelitian ini adalah menghasilkan suplemen bahan ajar tematik untuk kelas IV subtema ayo cintai lingkungan, fokus kajiannya materi pelestarian lingkungan. Hasil penelitian menunjukkan bahwa tingkat kelayakan bahan ajar sangat tinggi. Bahan ajar yang dihasilkan memiliki tingkat kevalidan sebesar 87,45 \%, kepraktisan sebesar 94,43\%, dan keefektifan sebesar $81,1 \%$. Dengan demikian dapat disimpulkan bahan ajar 82 tematik yang dikembangkan peneliti layak digunakan sebagai bahan ajar dalam proses pembelajaran. Penelitian dan pengembangan yang dilakukan oleh (Lestariningsih \& Suardiman, 2017), tentang pengembangan bahan ajar tematikintegratif berbasis kearifan lokal untuk meningkatkan karakter peduli dan tanggung jawab. Tujuan penelitian ini adalah (1) menghasilkan bahan ajar tematik integratif berbasis kearifan lokal yang layak untuk meningkatkan karakter peduli dan tanggung jawab siswa, dan (2) mengetahui keefektifan bahan ajar tematik integratif berbasis kearifan lokal untuk meningkatkan karakter perduli dan tanggung jawab siswa. Hasil penelitian menunjukkan bahwa berdasarkan uji-t berpasangan didapat signifikansi untuk karakter peduli pada kelas eksperimen 1 sebesar 0,00 dan kelas eksperimen 2 sebesar 0,00 dan karakter tanggung jawab pada kelas eksperimen 1 sebesar 0,00 dan kelas eksperimen 2 sebesar 0,00 yang berarti ada perbedaan yang signifikan karakter peduli dan tanggung jawab siswa sebelum dan sesudah mengikuti pembelajaran dengan menggunakan bahan ajar tematik intergratif berbasis kearifan lokal. Dengan dapat disimpulkan bahan ajar yang dikembangkan efektif untuk meningkatkan karakter peduli dan tanggung jawab siswa.

Penelitian diatas juga didukung oleh penelitian yang dilakukan oleh (Dewi et al., 2020) mengenai penerapan pembelajaran dengan multicultural dapat meningkatkan kemampuan berfikir kritis siswa. Hasil penelitian tersebut mengungkapkan, "Differences in students' critical thinking results showed that the average grade in the experiment class higher than the control class with $t$-test of 5.707 to 1.9944 t-table ( $d f=70, \alpha=5 \%$ ). Traditional game based on multicultural learning is able to encourage a critical attitude because it makes students more flexibility in thinking. It could be concluded that traditional games based on multicultural education can improve critical thinking in the student in all aspects".

Selain itu pengembangan bahan ajar ini mendapat respon positif dari guru maupun siswa hal ini terlihat dari hasil wawancara yang dilakukan dimana pengembangan bahan ajar berbasis 
multicultural sangat dibutuhkan dalam menunjang proses pembelajaran dan meningkatkan keterampilan berpikir kritis siswa. Pengembangan pembelajaran dengan mengembangkan bahan ajar Bahasa Indonesia berbasis multikultural ini juga dapat mempermudah guru dalam menyampaikan materi. Respon positif dari guru maupun siswa mengenai pengembangan bahan ajar berbasis multicultural ini juga sejalan dengan penelitian terdahulu yang dilakukan oleh (Fatmawati et al., 2018) tentang pengembangan modul pendidikan multicultural. Hasil penelitian menyatakan bahwa Pengembangan modul pendidikan multikultural mendapatkan respon positif dari guru dan peserta didik, Bagi guru, modul pendidikan multicultural yang telah dikembangkan dapat digunakan sebagai alat bantu dalam mengenalkan sikap multikultural, nasional, dan cinta tanah air pada peserta didiknya. Sedangkan bagi peserta didik, modul pendidikan multikultural merupakan salah satu media pembelajaran bagi peserta didik yang dapat digunakan sebagai alternatif belajar peserta didik disekolah maupun belajar mandiri di rumah. Penelitian (Suyanto et al., 2020) juga menemukan bahwa, "this study indicated that teachers of the elementary school and Islamic elementary school had positive perceptions of multicultural education because it is believed will be able to spread tolerant attitude and behavior to all students".

Pengaruh positif pembelajaran berbasis multicultural dalam meningkatkan kemampuan berfikir kritis diharapkan dapat menjadi refernsi bagi guru untuk mengembangkannya dalam pembelajaran. Guru juga dapat mengangkat potensi local di daerahnya. Penelitian yang dilakukan oleh (Utaminingsih \& Murtono, 2019) menemukan bahwa integrasi muatan local efektif meningkatkan kemampuan berfikir kritis siswa. Adapun hasil penelitian tersebut mengatakan, "Based on the results of the study, it can be concluded that the character of "gusjigang" contains important components of high-level thinking skills. Each character supports the components of complex analysis, critical thinking, classifying, reflective thinking, problemsolving, experimenting, information synthesizing, system analyzing, decision-making, and result in recommendation formulating abilities. The implication is the requirement to formulate an innovative education program and learning process to facilitate students in gaining experience in solving problems, exploring the environment and having adaptive behavior to the demands of their environment".

Lebih lanjut (Utaminingsih \& Zuliana, 2018) dalam penelitiannya menemukan bahwa, "The result of research can be get the design of model: integrated thematic learning based on local advantage in Demak municipalitythat can improve the quality of learning of elementary school students. Penelitian tersebut diperkuat oleh (Firdaus et al., 2019) menemukan hasil yang sama yaitu perangkat pembeajaran model inkuiri terintegrasi kearifan local, setelah diimplementasikan efetif dalam meningkatkan keterampilan berpikir kritis mahasiswa dalam pembelajaran ekologi. Sedangkan (Karakoc, 2016) berpendapat, "There are several ways of organizing for instruction in critical thinking: We can teach a separate course or unit,we can infuse critical thinking into all that we teach, or we can use a mixed approach. The first approach of a separate course or unit requires materials that teach specifically for critical thinking dispositions, skills, and knowledge".

\section{SIMPULAN}

1. Penggunaan Bahan ajar Bahasa Indonesia berbasis multikultural, siswa tertarik mempelajari pembelajaran yang berlangsung, mencoba dan membuktikan sendiri. Sehingga akan memperkuat kemampuan kognitif dan keterampilan berpikir kritis siswa, dengan demikian pembelajaran menjadi lebih bermakna.

2. Berdasarkan uji t tersebut maka dapat disimpulkan bahwa penerapan bahan ajar Bahasa Indonesia berbasis multikultural efektif dan layak digunakan dalam meningkatkan keterampilan berpikir kritis siswa kelas IV sekolah dasar di Kabupaten Jepara.

\section{UCAPAN TERIMAKASIH}

Kami ucapkan terima kasih atas Hibah Tesis dari Direktorat Penguatan Riset dan Pengabdian kepada Masyarakat Kementerian Riset Teknologi dan Pendidikan Tinggi yang telah membiayai penelitian ini mulai dari persiapan sampai pada penyusunan luaran berupa artikel penelitian. 
Efektifitas Pengembangan Buku Ajar Berbasis Nilai-Nilai Karakter Multikultural Terhadap

Keterampilan Berpikir Kritis Siswa (Sony Ari Wibowo, Murtono, Santoso, Sri Utaminingsih)

\section{DAFTAR PUSTAKA}

Ardianti, Sekar Dwi, Ulya, Himmatul., dan Ismaya, Erik Aditia. (2018). Pakem dalam Kurikulum 2013. Kudus: Badan Penerbit Universitas Muria Kudus.

Bahr, N. (2010). Thinking Critically about Critical Thinking in Higher Education. International Journal for the Scholarship of Teaching and Learning, 4(2), 0-16. https://doi.org/10.20429/ijsotl.2010.040209

Dewi, N. R., Rizkiana, F., Nurkhalisa, S., \& Dwijayanti, I. (2020). The effectiveness of Multicultural Education through traditional games-based inquiry toward improving the ability of critical thinking. Journal of Physics: Conference Series, 1521(4). https://doi.org/10.1088/1742$6596 / 1521 / 4 / 042125$

Fatmawati, L., Pratiwi, R. D., \& Erviana, V. Y. (2018). Pengembangan Modul Pendidikan Multikultural Berbasis Karakter Cinta Tanah Air dan Nasionalis pada Pembelajaran Tematik. Scholaria: Jurnal Pendidikan Dan Kebudayaan, 8(1), 80-92. https://doi.org/10.24246/j.js.2018.v8.i1.p8092

Firdaus, L., Samsuri, T., \& Susantini, E. (2019). Efektifitas Perangat Pembelajaran Inkuiri Terintegrasi Kearifan Lokal Terhadap Keterampilan Berpikir Kritis Mahasiswa. 2014, 269-281.

Indrawini, T., Amirudin, A., \& Widiati, U. (2017). Pengembangan Bahan Ajar Tematik Subtema Ayo Cintai Lingkungan Untuk Siswa Kelas IV SD. Jurnal Pendidikan:Teori, Penelitian, Dan Pengembangan.

Karakoc, M. (2016). The Significance of Critical Thinking Ability in Terms of Education. International Journal of Humanities and Social Science, 6(7), 81-84.

Lestariningsih, N., \& Suardiman, S. P. (2017). Pengembangan Bahan Ajar Tematik-Integratif Berbasis Kearifan Lokal untuk Meningkatkan Karakter Peduli dan Tanggung Jawab. Jurnal Pendidikan Karakter. https://doi.org/10.21831/jpk.v7i1.15503

Leung, A. K. yee, Maddux, W. W., Galinsky, A. D., \& Chiu, C. yue. (2008). Multicultural Experience Enhances Creativity: The When and How. American Psychologist. https://doi.org/10.1037/0003-066X.63.3.169

Melindawati, S. (2016). Pengembangan Bahan Ajar Tematik Terpadu dengan Model Problem Based Learning di Kelas IV Sekolah Dasar. Elementary School Journal Pgsd Fip Unimed. https://doi.org/10.24114/esjpgsd.v5i1.3974

Skills, P. for 21St C. (2011). Framework for 21st Century Learning. Partnership for 21 st Century Skills. https://doi.org/http://www.21stcenturyskills.org/documents/framework_

flyer_updated_jan_09_final-1.pdf

Suyanto, T., Suwanda, I. M., \& Umbase, R. S. (2020). Teacher's Perception about the Urgency and Benefits of Multicultural Education for Establishment of Student Tolerance Attitude. https://doi.org/10.2991/icss-18.2018.52

Utaminingsih, S., \& Murtono, M. (2019). Higher Order Thinking Skills (HOTS) in GUSJIGANG Culture and Character of Kudus People. https://doi.org/10.4108/eai.8-12-2018.2283941

Utaminingsih, S., \& Zuliana, E. (2018). Design Of Thematic Integrative Learning Based On Local Advantage In Elementry School. Refleksi Edukatika: Jurnal Ilmiah Kependidikan. https://doi.org/10.24176/re.v9i1.2811 